\title{
DE TIRANASY REINAS. ALGUNOS MODELOS DE VIOLENCIA FEMENINA DEL PODER EN CALDERÓN
}

\author{
Juan Manuel Escudero Baztán \\ Universidad de Navarra, GRISO \\ Edificio Biblioteca \\ 31009 Pamplona. España \\ jescudero@unav.es
}

En general, la literatura del siglo XvII es, en muchos casos, una literatura masculinizada, que define el mundo femenino a partir de sus propios parámetros, proyectando en esa imagen constructiva del otro sexo un conjunto de prejuicios, frustraciones y deseos que modelan una imagen determinada de la mujer, alejada a veces de la realidad cotidiana ${ }^{1}$. Todo esto, que es muy obvio, conlleva ciertas dificultades en la escritura literaria cuando se hace necesario configurar nuevos modelos, que no pueden ser creados ex nihilo, y que necesitan imperativamente ser fundamentados en otros anteriores. No se trata aquí de teorizar sobre la génesis del hecho literario, sino de constatar una vez más que la literatura, y en general todas las artes, guardan una apreciable dependencia con la posición de homo historicus de creadores y perceptores, y, por tanto, que se caracteriza por una mezcla heterogénea de valores atemporales y valores subtemporales, más perecederos. Ocurrió así con la novela picaresca, cuya poética expandió sus cauces expresivos con el ensayo del protagonista pícaro femenino, concebido desde la perspectiva imaginaria de la masculinidad que modeló una figura importada

\footnotetext{
${ }^{1}$ Remito a los trabajos pioneros de Stoll y Smith, 1991 y 2000.
} 
de los principios poéticos de la, muy entonces en boga, novela cortesana. El ensayo no produjo abundancia de títulos, a lo mejor porque la abrumadora monumentalidad del Guzmán de Alfarache dejó sin sentido cualquier extensión, pero sí puso en juego a una protagonista femenina que explotaba para sus propios fines lucrativos su belleza, aseo y atractivo sexual. Las pícaras, en este caso, focalizando el desiderátum de una perspectiva masculina, funcionaron como entes muy diferentes a sus homónimos masculinos. Sin embargo, en el teatro del diecisiete la cuestión funciona de otra manera, con diferentes principios que condicionan la perspectiva de la alteridad entre lo masculino y lo femenino. Siguió predominando la proyección masculina sobre el otro sexo, y así, el personaje femenino fue sometido a una escala de valoración cuyo vértice superior venía determinado por la conjunción de dos valores positivos: belleza y discreción. No obstante, la intensidad y manifestación dramática de ambos valores varía según la naturaleza de los roles dramáticos, que, a su vez, depende de su funcionalidad en un determinado género. No es lo mismo la presencia de un personaje femenino de alto rango en una tragedia o en una comedia, pues la desactivación de los valores constitutivos de la excelencia femenina es mucho más acusada en la tragedia que en una comedia cómica ${ }^{2}$. En la tragedia, la modelación de la hermosura y discreción como diseño global del personaje se atenúa y es sustituida por la preeminencia de pasiones, vicios y también virtudes que afectan por igual a hombres y mujeres. En este sentido, la caracterización del rol femenino de rango elevado funciona lejos de los esquemas tradicionales de lo que parte de la crítica ha llamado la «mujer varonil», porque no hay una complementariedad de género, sino una eliminación de la marca genérica (me refiero al gender). Se debe matizar un poco más la cuestión porque la pérdida del valor contrastivo del género tiene lugar en la esfera pública y no en la esfera privada del personaje. Esta diferenciación arranca ya desde la Edad Media a través de la metáfora de los dos cuerpos del rey ${ }^{3}$, el cuerpo natural y el cuerpo político, que funcionan de manera sincronizada, en tanto que el natural se subordina siempre al político. El primero es mortal y está sujeto a la enfermedad y al capricho de los vicios y pasiones (y también de las vir-

${ }^{2}$ Piénsese en la diferencia que media entre una Semíramis en La hija del aire y una Diana en El perro del hortelano.

${ }^{3}$ Ver numerosos ejemplos de la aplicación de esta metáfora política en González García, 1998, pp. 80-91. 
tudes, claro). Así lo explica, por ejemplo, Plowden en sus Commentaries or Reports, escritos bajo el reinado de Isabel I de Inglaterra"

Pues el rey tiene en sí dos cuerpos, $v$. gr. un cuerpo natural y un cuerpo político. Su cuerpo natural (considerado en sí mismo) es un cuerpo mortal y está sujeto a todas las dolencias que provienen de la Naturaleza y del azar; a las debilidades propias de la infancia o de la vejez, y todas aquellas flaquezas a las que están expuestos los cuerpos naturales de los otros hombres. Pero su cuerpo político es un cuerpo invisible e intangible, formado por la política y el gobierno y constituido para dirigir al pueblo y para la administración del bien común, y en ese cuerpo no cabe ni la infancia ni la vejez ni ningún otro defecto ni flaqueza natural a los que el cuerpo natural está sujeto, y por esta razón, lo que el rey hace con su cuerpo político no puede ser invalidado ni frustrado por ninguna de las incapacidades de su cuerpo natural.

Ambos cuerpos forman una unidad indisoluble, en la que el cuerpo político se encarga de borrar las debilidades del cuerpo natural. De manera que los posibles defectos del cuerpo natural pueden ser corregidos por el ejercicio del gobierno del bien común y la protección de los súbditos. Dada la supremacía del cuerpo político sobre las miserias corporales, este carece, en esencia, de asignación genérica, que queda ligada básicamente al cuerpo natural. Este esquema en apariencia dual - pero con claro predominio de la función política- explica en cierta manera cómo funciona en Calderón el concepto moral de «vencerse a sí mismo ${ }^{5}$ ", pues siempre el cuerpo político debería funcionar como corrector y atenuador de las malas inclinaciones del cuerpo natural. Pero a veces ocurre que las pasiones alojadas en el componente biológico del gobernante terminan por contaminar al cuerpo político, incapaz entonces de discernir entre el bien y el mal, entre el destino prefijado y la libertad, cuyo resultado final es la destrucción del personaje y, lo que es más injusto, el uso arbitrario de la violencia ${ }^{6}$. Sobre estos parámetros es indiferente que el tirano sea hombre o mujer, sus motivaciones, impulsos y actos violentos responden a una misma naturaleza.Y Calderón generalmente aplica una sola pasión: la ambición (y sus secuelas ancilares),

\footnotetext{
${ }^{4}$ Citado por Kantorowicz, 1985, pp. 19-20.

${ }^{5}$ Ver unos cuantos ejemplos calderonianos en Arellano, 2006.

${ }^{6}$ Aunque es cierto que los límites de la violencia y su percepción en el siglo XVII es diferente a la de un espectador del siglo xxi.Ver más detalles en Petro del Barrio, 2006.
} 
con tendencia a focalizarla como fuerza destructora del hado o ejercicio de la libertad individual. Reflejo en todo caso del fracaso del individuo en la gestión de las vicisitudes de su propia existencia. Todo esto explica en parte la caracterización de estos reyes y reinas en sus motivaciones y comportamientos desalmados. Pero no es menos cierto que, desde la perspectiva de la arquitectura teatral, la tiranía y violencia que ejercen sobre la colectividad, y por tanto la imposibilidad en el dominio de sus pasiones, se encuentran limitadas por dos principios dramáticos insoslayables: el género dramático y el decoro.

El género es fundamental porque determina la transcendencia de las implicaciones serias del ejercicio arbitrario del poder de las reinas calderonianas y, por ende, el alcance efectivo del ejercicio de su violencia ${ }^{7}$. Serían, por ejemplo, inexistentes en el territorio de la comedia cómica de capa y espada o de la comedia palatina, y también muy dificiles de cuantificar en otros géneros más cercanos al territorio de lo serio como las comedias hagiográficas, en las que, sin embargo, hay estupendos ejemplos del ejercicio femenino de la violencia de personajes particulares como el caso de Julia en La devoción de la $\mathrm{cruz}^{8}$. El terreno más fértil sería, sin duda, el constituido por «el género intermedio de la comedia de corte ${ }^{9}$ " y la tragedia, pues en ambos hay numerosos ejemplos de tiranas que hacen un uso irracional y arbitrario de la violencia. Sin embargo, a pesar de la existencia de cierto patetismo en las comedias áulicas de gran espectáculo (muy relacionado con el peso del argumento mitológico de sus fuentes) y de posibles alusiones morales, políticas e ideológicas, estas quedan fijadas dentro del marco de convenciones del juego cortesano y de la manifestación de mecanismos identitarios de pertenencia de grupo $^{10}$. Son, en suma, artefactos eminentemente lúdicos (con ingredientes cómicos, si se quiere) que desactivan las posibles conflictividades del uso de la violencia femenina, y que acercan estos modelos a los estereotipos femeninos de hermosura e ingenio como le

${ }^{7}$ Con acierto estudia Arellano (2015) las implicaciones genéricas en el diseño de las mujeres perversas en Calderón. Para algunos ejemplos de la violencia calderoniana en sus dramas, ver Arellano, 2009. Y también Escudero Baztán, 2014, en relación con los sueños.

${ }^{8}$ Que por otra parte es una comedia que sufre contaminación de otros posibles géneros teatrales como la comedia de bandoleros. Ver más detalles en McKendrick, 2010. Y también la introducción a la edición de La devoción de la cruz de Sáez, 2014.

${ }^{9}$ En palabras de Arellano, 2015, p. 35.

${ }^{10}$ Ver Escudero Baztán, 2016. 
ocurre a Circe en El mayor encanto, amor donde la pasión rectora de su ambición se deslíe en una historia sentimental y en un triángulo amoroso entre Circe, Arsidas y Ulises ${ }^{11}$, o a Medea en Los tres mayores prodigios, a quien se la retrata como soberbia, vanidosa, impía y blasfema, pero cuya supuesta violencia es realmente inicua, diluyéndose en el constante juego de jardines, academias de amor y refinamientos cortesanos de la puesta en escena; en suma, todos los ingredientes del entretenimiento áulico ${ }^{12}$. La tragedia, sin embargo, es terreno más abonado para la plasmación en escena de la violencia irracional de estas heroínas, cuyo ejercicio del poder es arbitrario y su violencia injusta, en tanto que su irracionalidad es potenciadora misma de la tragicidad en casos tan llamativos como el de Ana Bolena o Semíramis (que tiene un contramodelo en la figura de Cenobia). En las dos primeras el cuerpo natural inficiona su cuerpo político hasta acabar con él; la tercera es un ejemplo atípico de síntesis asimilativa.

El decoro, por otra parte, es fundamental para entender en este caso los cambios que Calderón realiza en las pasiones rectores en el plano privado de sus protagonistas, que arrastran una serie de secuelas caracterizadoras derivadas de la óptica histórica de este tipo de tragedias. En un principio le son impuestas al dramaturgo por medio de las fuentes sobre las que levanta el andamiaje dramático, y que modifica con entera libertad, pues son pasiones inaceptables e innobles en un personaje alto $^{13}$. Estas pasiones de nueva planta — la vanidad y la ambición, sobre todo- (que terminan siendo un ente incontrolable y destructor), son preferidas por Calderón por su carácter neutro frente a otras de asignación más femenina por influencia de la sátira misógina como la lujuria y la concupiscencia. Pero Calderón, cuando le conviene, es muy respetuoso y coherente con el empleo de la fuente, y sobre todo calibra bien su grado de conocimiento por el receptor, pues nunca las borra del todo.

Este apretado panorama tiene reflejo en tres ejemplos magníficos calderonianos: La cisma de Ingalaterra, La hija del aire (primera y segunda parte) y La gran Cenobia.

${ }^{11}$ Sin ningún tipo de implicación trágica ni política y mucho más cercana al puro juego de ingenio.Ver más detalles en Fernández Mosquera, 2008b.Y la introducción de Ulla Lorenzo a su edición del texto (2013).

${ }^{12}$ Ver Arellano, 2015, p. 35. Ver más detalles en Fernández Mosquera, 2008a, y en la introducción del propio Mosquera a la edición del texto en Biblioteca Castro, 2007.

${ }^{13}$ Ver Escudero Baztán, 2000 y 2001. 
La cisma de Ingalaterra es, sin duda, una de las mejores tragedias calderonianas, tanto por su factura clásica, al cumplir con escrúpulo las características canónicas del género ${ }^{14}$, como por su admirable construcción a partir de los vaivenes de la diosa Fortuna y de las ambiciones rectoras que mueven a los personajes ${ }^{15}$. La fuente utilizada por Calderón es el libro primero (de 1588) de la Historia eclesiástica del cisma del reino de Inglaterra ${ }^{16}$ del padre jesuita Pedro de Ribadeneira ${ }^{17}$, quien toma a su vez como fuente la obra de Nicholas Sander ${ }^{18}$, De origine ac progressu schismatis anglicani, completada por Edward Rishton y publicada en Colonia en 1585 , de la que hace una traducción muy libre ${ }^{19}$.

Como tragedia basada en hechos reales ${ }^{20}$, su sustancia histórica impregna no solo los engranajes de su mecanismo trágico, sino también

${ }^{14}$ Remito para la construcción trágica a la introducción de Escudero Baztán en su edición de la obra (2001).

${ }^{15}$ La comedia pudo escribirse según Hilborn, 1938, p. 38, hacia 1634; para Parker, 1948, reimpreso en 1973, p. 77, quizá «después del estallido de la guerra civil inglesa, y quizá incluso después de la ejecución de Carlos I» de Inglaterra en 1649. Shergold y Varey, 1961, p. 277, adelantan la fecha de composición antes del 31 de marzo de 1627.

${ }^{16}$ Ver la edición de De la Fuente a sus Obras escogidas, 1952. La introducción ocupa las pp. 177-79, cita en p. 177. El texto, pp. 181-357.

${ }^{17}$ En el siglo XVII es «una de las obras más populares de España», como escribe De la Fuente en su introducción a la edición del texto, popularidad refrendada por el testimonio del propio monarca Felipe IV quien lo tenía como una de sus lecturas favoritas.Ver "Autosemblanza de Felipe IV», «Apéndice II» de las Cartas de Sor María de Jesús de Agreda $y$ de Felipe IV, 1958, p. 232b. Este fragmento epistolar es recogido por Fox, 1986, p. 7.

${ }^{18}$ Según manifiesta en el «Prólogo al lector»: «El parecerme obra provechosa me ha movido a poner la mano en ella, y a querer escribir en nuestra lengua castellana la parte della, que he juzgado es bien sepan todos, cercenando algunas cosas, y añadiendo otras, que están en otros graves autores de nuestros tiempos y tocan al mismo cisma. Ver los preliminares de la tercera edición de la obra: Madrid, Imprenta Real, 1674, a costa de Florián Anisón, mercader de libros. Todas las citas están tomadas de esta edición.

${ }^{19}$ Los indicios que permiten identificar el relato de Rivadeneira, y no el de Sander como fuente de Calderón, han sido recogidos entre otros Parker y Cabantous, y a ellos me remito para mayores precisiones (ver Parker, 1991, pp. 309-310; Cabantous, 1968, p. 44).

${ }^{20}$ No comparto la idea de Paredes, 1983, vol. I, pp. 541-548, quien ve la obra bajo la etiqueta genérica de «metateatro». No creo que la Cisma, siguiendo las teorías de Lionel Abel, cumpla las condiciones de «obra dramática de naturaleza filosófica... que toma vida a partir de valores que son importantes fuera del drama... que conciben el mundo como algo teatral... producto de la imaginación del autor... y donde los personajes son autoconscientes de su teatralidad...» (p. 543). 
todos los elementos constructivos que organizan la estructura dramática de la tragedia. Pero una cosa es esta sustancia histórica que recorre la obra y otra bien distinta la arquitectura de un drama concebido bajo los códigos de escritura vigentes de la comedia española aurisecular. Ambos caminos no colisionan, sino que, sincronizados, organizan el conjunto de un drama de hondas implicaciones trágicas. Posiblemente, dicha mixtura alcance su mayor ejemplificación en la construcción de los personajes. Lo variable de esta mezcla en cada caso particular posibilita la existencia de tres niveles diferentes ${ }^{21}$. El cambio más significativo ocurre con el rey EnriqueVIII, piedra angular del entramado trágico de la obra, y con el personaje de Ana Bolena, al que se le puede aplicar el principio constructivo que he señalado antes, pues su análisis admite, sin ningún tipo de dudas, la dicotomía entre el cuerpo natural y el cuerpo político - plenamente visible cuando Bolena inicia su ascenso al trono inglés en calidad de consorte real-; la efectiva función correctora del decoro dramático ${ }^{22}$, y también la explotación de marcas de configuración femenina, belleza fisica y atracción erótica, relevantes desde la perspectiva masculina y la obvia masculinización de los roles dramáticos. Estos dos últimos elementos son señalados por Rivadeneira en numerosos pasajes de la fuente histórica, y ofrecen una visión cercana a lo grotesco en la descripción física de Bolena:

Era Ana alta de cuerpo, el cabello negro, la cara larga, el color algo amarillo, como atiriciado, entre los dientes de arriba le salía uno que la afeaba; tenía seis dedos en la mano derecha, y una hinchazón como papera, y para cubrirla, comenzó ella, y siguiéronla otras, a usar un alzacuello. El resto del cuerpo era muy proporcionado y hermoso. (cap. 7, p. 24b)

Y, de manera insistente, en su lascivia proverbial:

${ }^{21}$ Cabría considerar tres grandes grupos: 1) personajes en los que priman las convenciones estéticas de la fórmula dramática por encima de su «sustancia histórica»; 2) personajes donde prima la «sustancia histórica», sin que se aprecie una desviación significativa de su personalidad con respecto a la reflejada por Rivadeneira en la fuente como le ocurre al cardenal Volseo; y 3) personajes eminentemente históricos, pero en los que las convenciones constructivas del sistema de personajes de la comedia nueva operan cambios radicales en su personalidad, que divergen totalmente de la fuente (ver para más detalles de esta clasificación Escudero Baztán, 2001).

${ }^{22}$ Ver Escudero Baztán, 2000 y 2001. 
Siendo muchacha de quince años, se revolvió con dos criados de su mismo padre putativo Tomás Boleno. Después fue enviada a Francia, y habiendo entrado en el palacio real, vivió con tan grande liviandad, que públicamente era llamada de los franceses la jaca o yegua inglesa, y después la llamaban mula regia, por haber tenido con el rey de Francia amistad. (cap. 7, p. 24b)

Pero para Calderón, y desde el punto de vista de la construcción dramática y de la observancia del decoro dentro de los parámetros de la tragedia, era necesario primero corregir las ambigüedades de la fuente con respecto a la exaltación de la belleza fisica de la protagonista (que en el texto se atiene a la ortodoxia y usos establecidos por la tipificada retórica petrarquista ${ }^{23}$ ), y en atemperar esas referencias explícitas a su promiscuidad sexual. No se trata de su anulación, sino de un proceso de solapamiento con otras pasiones destructoras, más adecuadas al entorno áulico en que se mueve el personaje, y que se manifiestan a través del ejercicio de la violencia en el sometimiento caprichoso del rey, y en el proyectado asesinato de sus adversarios políticos:Volseo, la reina Catalina y la infanta María ${ }^{24}$. De esta manera, con medida sutileza, Calderón superpone a la concupiscencia la preeminencia de la vanidad, que es, en definitiva, la pasión que primero verbaliza en escena Ana Bolena. Pero es necesario recordar, que es el personaje junto con Enrique VIII con que se inicia la comedia, esa «sombra divina, imagen bella / sol eclipsado, deslucida estrella» (vv. 1-2), manifestándose carnalmente al final de la primera jornada, y significando con ello el principio de la pasión ciega del rey, cuyo discurso muestra con claridad la fragmentación de su conciencia ${ }^{25}$ (vv. 855-868). Y también que en el parlamento de factura petrarquista que hace Carlos, embajador de Francia, a la belleza de Bolena se explicita al final su entrega carnal. Aquí, Calderón ha optado por la función amortiguada de la observancia del decoro.

${ }^{23}$ Recuérdese el elaborado retrato que hace de ella Carlos, embajador de Francia, en octavas reales (vv. 333-444).

${ }^{24}$ Ana Bolena solo conseguirá el de la reina Catalina a través de una carta envenenada. Recuérdese que Ana Bolena se casa en secreto con Enrique VIII, lo que supone un cumplimiento imperfecto de su ambición. La violencia que desata es instrumental, dirigida a su nombramiento como verdadera reina de Inglaterra.

${ }^{25}$ Como apunta Ruiz Ramón (1984, p. 80) es esta «división de la conciencia de Enrique la que va a constituirse en núcleo dramático de la acción del Acto II, cuyo eje temático, de donde parten y a donde confluyen todas las fuerzas en conflicto, es el proceso de mudanza del rey, causa y efecto, a la vez, de la conjunción trágica de la libertad y el destino». 
Su primera aparición en escena tiene lugar en palacio y ante la reina, y es Pasquín quien la retrata a través de una profecía que, asentada en su locura, resulta clarividente (vv. 613-632):

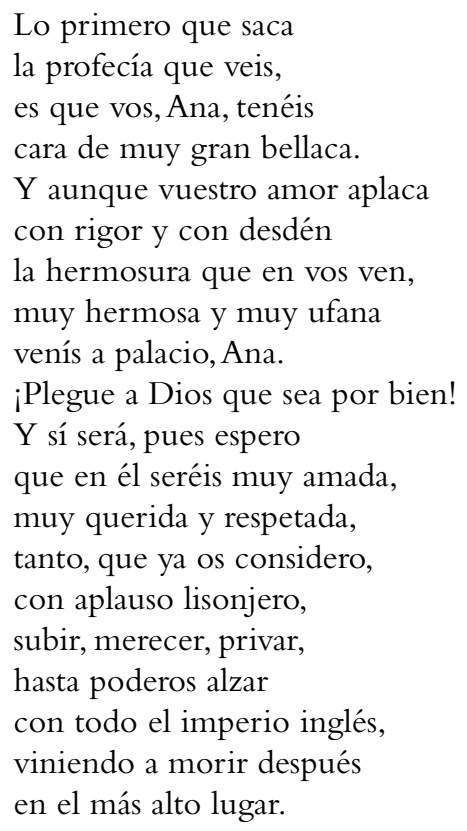

Lo que caracteriza a Ana Bolena es su ambición y soberbia, apenas disimuladas cuando recibe los consejos de su padre ${ }^{26}$. Las palabras finales de Tomás tendrán carácter profético: «Dios hay, y aunque soy tu padre, / tal vez podrá ser que niegue / la sangre por el honor, / y no rehusaré tu muerte» (vv. 755-58). Esta pequeña confrontación entre padre e hija, muy significativa, revela al espectador la imposibilidad de confiar en la verdad del amor que Ana promete a Carlos. Nótese con qué habilidad Calderón trunca la respuesta de Ana a la palabra de esposo que le ofrece Carlos ante la súbita llegada de la reina y el rey (vv. 824-830):

ANA

Pues ¿qué serás?

CARLOS

Tuyo siempre.

26 «iYo la rodilla en la tierra! / ¡Yo besar con rostro alegre / la mano a la reina, aunque / de cuatro imperios lo fuese!» (vv. 727-730). 
ANA

Carlos

ANA

CARlos

ANA
¿Quién lo asegura?

Esta mano.

¿De esposo?

$$
\begin{aligned}
& \text { Digo mil veces } \\
& \text { que sí, aunque mi padre ingrato }
\end{aligned}
$$
en Francia casarme quiere. Mas agora estoy en Londres.

La reina con el rey vuelve.

Es obvio que la íntima declaración que hace Carlos no es recíproca. Las cortas respuestas de Ana, formuladas casi de manera evasiva, alimentan más el fuego amoroso de su amante.Aquí el desvío con respecto a la fuente es fundamental y los mecanismos del cambio, como ocurre con Enrique VIII, son muy parecidos y merecerían un comentario más extenso. Además, vanidad y ambición en este caso propician una interacción más natural con la diosa Fortuna.Y por si esto no fuera suficiente, Calderón entrevió con lucidez la plusvalía en el juego dramático de dos seres ambiciosos, Volseo y Bolena, enfrentados entre sí y abocados en su mutua destrucción. El desenlace catastrófico es inevitable. Llegada a lo alto, la rueda de la Fortuna comienza a caer. La caída de Ana Bolena es capricho del azar, pues es el resultado fortuito del motivo común del escondite del rey para observar cómo se comportan sus vasallos ante los últimos avatares de su reino. Accidentalmente, pues, descubre el billete amoroso que la incrimina.Y ordena su prisión y muerte a manos de su progenitor $^{27}$. Calderón atempera las razones de la ejecución de Ana, al reducirlas esencialmente a un caso de imprudencia fatal, consecuencia de su ambición descontrolada, incapaz de renunciar a su sentimiento amoroso (bastante ambiguo como he señalado) por Carlos, en favor del fingido que siente por el rey. No sigue a Rivadeneira, que centra las razones de su ejecución en el aburrimiento del rey (aficionado a Juana Semeira), y, de nuevo, a su desmedida lascivia ${ }^{28}$.

${ }^{27}$ De nuevo otro personaje que debe actuar trágicamente en su doble dimensión de juez y padre como le ocurría a Pedro Crespo en El alcalde de Zalamea.

28 «El rey se comenzó a cansar de Ana, y aficionarse a una doncella de las que la servían, llamada Jana Semeira [...] después que [Ana] parió a Isabel, y pareciéndole que, pues no había tenido hasta entonces hijo varón del rey, tampoco le podría tener adelante, y que pues era mujer de rey, era justo que también fuese madre de rey, $[\ldots]$ por más secreto convidó con su cuerpo a Jorge Boleno, su hermano, y tuvo abominable ayun- 
La ambición, al final, se establece como una fuerza destructora que no legitima en ningún momento su cuerpo político, pero sí extiende lo lesivo de su violencia en otros personajes con diverso grado de culpabilidad, pues media una gran distancia moral entre la aniquilación total del cuerpo político del rey (que busca su reparación a través de la jura de la infanta María) y el estatus de víctima trágica de la reina Catalina, que representa el punto justo de injusticia necesario para que la tragedia resulte efectiva en su función ejemplar y catártica.

El caso de la reina Semíramis en las dos partes que componen el díptico de La hija del aire es análogo en muchos sentidos pero también diferente en otros aspectos básicos de su configuración trágica. Operan los mismos principios de la pertinencia de la doble metáfora del cuerpo del rey, la puesta en funcionamiento de las armas femeninas (belleza y seducción) junto con imperativos de construcción dramática a partir de la observancia del decoro, aunque este último presenta algunos matices que precisan cierta aclaración.

A diferencia de La cisma de Ingalaterra, Calderón utilizó como fuentes inmediatas tres textos de épocas muy diferentes: la Biblioteca Histórica de Diodoro Sículo (escrita en el siglo I a. C.) (9) $^{29}$ la principal, fuente a su vez de las otras dos-; la obra de Sabellico Rapsodiae Historicae Enneadum (1498); y La gran Semíramis de Virués (escrita con probabilidad hacia 1609). Cada una de las tres le sirvió a Calderón para elaborar una acción dramática y un diseño de los personajes acordes con la escritura de una tragedia canónica sobre el destino y la libertad. A esto se le une,

tamiento con él, pero no le sucedió lo que deseaba; porque no le nacieron hijos, y [...] se determinó con otros; de manera que no solamente se aficionó a algunos hombres nobles, y tuvo acceso con ellos, mas también con un músico o maestro de danzar, que se llamaba Marcos, hijo, como algunos dicen, de un carpintero. Y como eran muchos los amigos de Ana, y ella era libre y muy osada, no se pudo encubrir su maldad al rey. Pero él con extraña disimulación calló hasta que un día [...] los ministros de justicia la estaban aguardando para llevarla presa al castillo de Londres, que está sobre el mismo río. Cuando se vio prender Ana, al principio comenzó a maravillarse y a embravecerse, después a quejarse y a lamentarse, y finalmente a rogar y suplicar que la llevasen delante del rey. [...] Sacáronla de la cárcel donde estaba, y lleváronla públicamente al tribunal; presentáronla delante de los jueces, [...] y siendo convencida de adulterio y del incesto con su hermano, fue condenada a muerte, y a los diez y nueve de mayo le fue cortada la cabeza públicamente [...]. Tres días después que se hizo la justicia de Ana, fueron también ajusticiados sus amigos y galanes» (cap. 34, pp. 109b-110b).

${ }^{29}$ La edición príncipe de Diodoro fue una traducción latina de los cinco primeros libros, realizada por Poggio Bracciolli en Bolonia en 1472. 
de nuevo, las convenciones dramáticas de la Comedia Nueva que expurgan (en este caso no hay ocultamiento) a Semíramis de defectos presentes en el mito pero impropios de un personaje real, como la lujuria y el posterior asesinato de los amantes, señalados por Diodoro, Sabellico y mantenidos por Virués; o el deseo incestuoso de Semíramis hacia su hijo Nimias recogido por Sabellico y Virués en su tragedia ${ }^{30}$, que recogen una tradición extendida en el tiempo que consideran a Semíramis como prototipo de mujer seductora y lasciva ${ }^{31}$, pero que convive con otra tradición mucho más benigna en el retrato de los vicios carnales de la protagonista ${ }^{32}$. Además, como a Calderón le interesa mucho más vertebrar su obra bajo el prisma de la oposición trágica entre destino y libertad, Semíramis desde un principio se encuentra encorsetada bajo los designios del hado y la guerra soterrada entre las divinidades de Diana

30 «Calderón omits her legendary eroticism and her incestuous love for her son, and, except for one superbly dramatic moment, plays down Semíramis's abilities and achievements as a military and civil leader. He neglects, in other words, the sensational features of her historical persona and replaces them with a beautifully constructed twopart study of the inner workings of an ambitious soul, of a personality whose gigantic energy is directed solely towards the projection of self, towards a total fulfilment of will» (ver Mckendrick, 1974, p. 203).

${ }^{31}$ Como ejemplo de la vertiente concupiscente remito a esta cita de Boccaccio: «Esta bellaca mujer ensució con una sola suciedad y flaqueza, ca encendida entre otras de una continua comezón de lujuria, la desaventurada, según se cree, se dio a muchos, y entre sus enamorados se cuenta su mismo fijo, mancebo de muy fermosa disposición. El cual, después de haberse echado con su madre y habido parte con ella por lugar no debido, cosa por cierto más abominable y bestial que humana, mientras ella sudaba peleando contra los enemigos en el campo estaba él con la pierna tendida, ocioso en el tálamo y estrado [...]. De la cual, amancillada Semíramis, pensando de quitar con astucia lo que había con su disolución ensuciado, dicen que fizo aquella insigne ley en donde permitía a sus súbditos que acerca las cosas de la carne y apetitos de lujuria ficiesen lo que les pluguiese. [...] otros escriben que como se hobiese enamorado de su fijo, y siendo ya de edad provecta se hobiese echado con él después de haber reinado treinta y dos años, la mató. De los cuales discuerdan otros, afirmando que ella mezcló crueza con la lujuria, y dicen haber ella acostumbrado que a los que llamaba para cumplir sus carnales apetitos y el fuego de su disolución y deseos desordenados, por encubrir su maldad, luego después de haber pasado sus deleites con ellos, mandaba matarlos» (ver Boccaccio, De las mujeres ilustres en romance, 1494, fol. 6r y ss.).

32 Como apunta Mckendrick (1994, p. 164) «el retrato de Semíramis está hermosamente construido y capta nuestros sentimientos, equilibradamente escindidos entre la desaprobación y la simpatía. Para conseguirlo - y no únicamente por razones de decoro-, Calderón ha expurgado la historia tradicional». 
y Venus. Aunque será finalmente el mal ejercicio de su libre albedrío el que disponga los hilos necesarios para la génesis de la tragedia:

¿Qué importa que mi ambición

digan que ha de despeñarme

del lugar más superior,

si para vencerla a ella

tengo entendimiento yo? (I, 148-52 33 )

Examinando La hija del aire se percibe que cada parte presenta dos momentos diferenciados del mito: la primera parte gira alrededor del origen de Semíramis, su encuentro con Menón y Nino, el enfrentamiento entre ambos y la coronación de la joven; mientras que la segunda se centra en el ejercicio del poder por parte de la reina. Calderón hace girar la acción en torno a un único personaje, Semíramis, con una única motivación existencial: el poder. La protagonista encarna la ambición desmedida y este carácter se perfila ya desde sus primeras intervenciones en la cueva, aunque a lo largo de la segunda parte llegará a su completo desarrollo. De esta forma la primera parte sería el camino y ascensión de Semíramis al poder mientras que la segunda parte dramatiza su caída y muerte. Toda la evolución argumental y, por lo tanto, la estructura que la fija, se orienta en este sentido, desechando el dramaturgo otros elementos que no guardan relación directa con el tema nuclear ${ }^{34}$.

La ambición y el deseo de poder se relacionan con la fatalidad, en conflicto con la libertad. Desde el inicio de la Primera parte la propia Semíramis anuncia su futuro, aunque existe la posibilidad de eludir el presagio, pues las estrellas inclinan pero no fuerzan:

\author{
pues advertida \\ voy ya de los hados míos, \\ sabré vencerlos, pues sé, \\ aunque sé poco, que impío
}

${ }^{33}$ Cito siempre por la edición de Baztán Salaverri, en preparación.

${ }^{34}$ Como señala Edwards: «His method consisted of discarding all irrelevant material, reshaping borrowed material, and introducing much that was new. Thus in the Primera parte Calderón's changes regarding the Nino-Semíramis-Menón relationship changes involving situation and character- allow the theme of lust to emerge with great power. [...] In the Segunda parte the theme of ambition is developed in similar fashion, the source material moulded to suit Calderón's purpose and fresh material introduced to underscore» (1966, pp. 195-196). 
el cielo no avasalló

la elección de nuestro juicio. (I, vv. 969-74)

El hado será la conexión de los tres temas fundamentales ${ }^{35}$ : la lucha entre la libertad y el destino, la naturaleza centáurica o monstruosa de la protagonista, y el poder; marcando, además, la circularidad de la acción trágica y determinando el avance de esta y sus niveles de sentido. El enfrentamiento entre libertad-destino ${ }^{36}$ remite a una situación anterior de la propia Semíramis, produciendo una violencia primitiva que convierte a la protagonista en víctima y no en agente. El desafio a los dioses marca su grandeza como personaje trágico; pero para romper la prisión en la que permanece encerrada necesita la ayuda de otros personajes (Menón y Nino) quienes con su liberación, sueltan también la violencia y actúan al servicio de un destino que solo se realiza en la libertad y por esta misma. No hay que olvidar que este tema está ligado al del poder. Este se desarrolla plenamente en la segunda parte entre dos actos de violencia - dos guerras contra Lidoro-, y a través del tema del doble encarnado en Semíramis-Nimias y Friso-Licas.

Todo este motor trágico está envuelto en la violencia que rodea, padece y desprende la protagonista. Semíramis ya está marcada por la violencia en su concepción al ser fruto de una agresión sexual, acentuada por el asesinato del padre y la muerte materna en el parto; «víbora humana» (I, v. 875) según Calderón, quien además la va a rodear de una serie de signos funestos anunciadores del destino fatídico de Semíramis. Esta violencia original del nacimiento se acompaña de un horóscopo y su lectura por un intérprete, quien decide aislar del mundo al recién nacido como protección contra la nefasta violencia de la que es portador; produciendo de este modo más violencia. Por lo tanto, el bien colectivo es prioritario ante el bien individual, pero Calderón va más allá mostrando que el sacrificio por la colectividad introduce violencia, generando así el mal que se pretendía evitar. A todo esto se le une la imagen de la gruta, asociada a una topografia de la violencia, y descrita

${ }^{35}$ Ruiz Ramón, 1987, p. 233.

${ }^{36}$ Ruiz Ramón, que al analizar el conjunto de las tragedias calderonianas, establece dos grupos: las basadas en el conflicto libertad-destino, y las que giran en torno al honor, considera a La hija del aire próxima al primer grupo al primero, pues su esquema trágico está definido entre otros principios por el de la circularidad (ver una exposición más completa en Ruiz Ramón, 1984, pp. 3-5). 
a través de efectistas imágenes, y la manifestación escénica de Semíramis a través de una violenta retahíla de golpes e imprecaciones.

Pero la característica más definitoria de Semíramis es su ambición, alojada y enraizada con fuerza en la esencia misma de su ser; no es simplemente una mujer ambiciosa, sino que este deseo posee al personaje ${ }^{37}$; a diferencia de otras Semíramis, la que presenta Calderón está dominada por el deseo de poder, no por el de la lujuria y la lascivia ${ }^{38}$. Hay dos aspectos básicos que muestran su deseo de poder: el desencanto que sufre al conocer la ciudad más magnífica del mundo, Nínive, y la posterior superación de esta en la segunda parte con la construcción de Babilonia; y la inmensa rabia que siente ante la rebelión de su pueblo, que no es digno de tenerla como reina, por lo que abdica. Desde la perspectiva metafórica del doble cuerpo del monarca, el cuerpo natural y contingente sufre una hipertrofia de la pasión de la ambición creciente que desborda los límites de su racionalidad, para instalarse en su imaginación, y terminar por contaminar su cuerpo político. En este sentido, la imaginación descontrolada de la protagonista es, según Rogers ${ }^{39}$, quien mueve la ambición insaciable del personaje. Mientras Semíramis ha permanecido encerrada solo ha podido imaginar cómo era la vida que se le privaba y su idea era más grandiosa que la realidad. Al no encontrar el reflejo de sus pensamientos en la realidad tangible, decide transformarla de acuerdo a sus peregrinas veleidades (I, vv. 2407-2410).

A pesar de sus deseos de poder, Semíramis no presenta en la primera comedia la crueldad que desarrolla en la segunda parte, cuando consigue su objetivo de ser reina de Siria. Entonces su ambición la domina por completo, convirtiéndose en su propia esencia:

sin reinar no tengo vida.

Mi ser era mi reino;

sin ser estoy, supuesto que no reino.

${ }^{37}$ Calderón, «La hija del aire», Tragedias de Pedro Calderón de la Barca I, ed. Ruiz Ramón, 1967, pp. 20-28. Esta opinión es compartida por otros muchos críticos como Hesse, 1983; Rogers, 1970; Calderón, Obras completas, ed.Valbuena Briones, 1959, tomo I, pp. 1003-09; Valbuena Briones, 1965c, pp. 230-38; Edwards, 1967, pp. 177-192; y González Velasco, 1989, pp. 43-53.

${ }^{38}$ Sobre otras Semíramis consultar Shapiro 1975; Sargent 1930; Caparrós Escalante, 1986.

${ }^{39}$ Rogers, 1970. 
Mi honor mi imperio era, sin él honor no tengo. (II, vv. 2165-69)

¿Yo sin mandar? De ira rabio. ¿Yo sin reinar? Pierdo el juicio. (II, vv. 877-78)

Semíramis por conseguir el poder es capaz de matar a Nino, y por recuperarlo de raptar a su hijo y usurpar el trono, lo que introduce una variante en el desarrollo del armazón trágico poco usual en Calderón y que merece, cuanto menos, una pequeña glosa - para ir concluyendoporque es el resultado del poder corrosivo de su ambición capaz de anular los vínculos materno-filiales. Semíramis ni siente ni ejerce como madre. En ella solo existe la ambición. Mide todo desde su posición de reina y no de madre; los sentimientos amorosos están anulados debido a su orgullo y deseo de poder. Dumézil ${ }^{40}$ ya señaló el aspecto político del mito de Urano, Cronos y Zeus por el que entre los portadores de una misma sangre real siempre hay competencia natural, amenaza y violencia por la obtención del trono ${ }^{41}$. De este modo, Faliu-Lacourt ${ }^{42}$ ve en Semíramis una madre castradora que corta la libertad de su hijo porque lo considera un rival y un peligro para su permanencia en el poder; motivo por el que lo aborrece. Esta rivalidad siempre es unidireccional, ya que Nimias se presenta ajeno a ella, mostrando respeto hacia sus progenitores desde su entrada en Babilonia. Pero ante los demás personajes, la reina esgrime otro motivo para usurpar el poder: lo hace por el bien del pueblo, ya que Nimias no posee el carácter adecuado para reinar:

Es Nimias, según me dicen, temeroso por extremo, cobarde y afeminado. (II, vv. 419-21)

Desde luego, Semíramis no es una madre modelo guiada por su amor maternal. Podría pensarse, desde una perspectiva dramática de acciones y reacciones, que sobre sus relaciones materno-filiales pesa la prehistoria de Arceta, su madre, violada por un joven al que mata como

${ }^{40}$ La referencia a Dumézil (1934, es comentada en detalle por Delcourt, 1981, pp. 82-83) la cita Ruiz Ramón (1992, p. 61).

${ }^{41}$ Ruiz Ramón (1992) señaló los puntos coincidentes entre este mito y La vida es sueño, que a la vez se manifestarían de igual modo en La hija del aire.

${ }^{42}$ Faliu-Lacourt, 1979. 
venganza, lo que constituye una marca indeleble que explican el porvenir y el comportamiento patológico de Semíramis ${ }^{43}$.

En suma, nos encontramos ante uno de los caracteres del teatro calderoniano mejor delineados, comparable, sin duda, a personajes shakesperianos de la talla de un Macbeth ${ }^{44}$ o un Ricardo III $^{45}$; y que puede considerarse, (y enfatizo) en algunos aspectos, como la réplica femenina de Segismundo ${ }^{46}$ :

La hija del aire, en su estructura básica, en los conflictos que plantea y en el significado, es similar a La vida es sueño; pero las actitudes que adoptan los protagonistas para la resolución del conflicto planteado y la suerte final de ambos son opuestas. Segismundo triunfa de su destino y en su libertad gana la mayor de las batallas que puede ganar el hombre: el vencimiento de sí mismo; Semíramis cambia también su destino y logra la ansiada libertad, pero no sabe usar de ella; pone su libertad al servicio del destino, no para luchar contra él, sino para llevar a cabo su cumplimiento ${ }^{47}$.

Y termino con un último ejemplo que trato de forma muy esquemática al tratarse en realidad de un contramodelo, con exposición de modos de conducta alejados del ejercicio de la violencia. A esta Semíramis tirana podría oponerse una reina modélica, la gran Cenobia, de la obra del mismo título. Modélica porque tanto su cuerpo natural como su cuerpo político manifiestan al unísono una constelación armoniosa de diferentes virtudes. A diferencia de Bolena y Semíramis, el ejercicio que hace de la violencia es legítimo, y está justificado como respuesta ante las acciones crueles del tirano Aureliano. Su violencia en este caso es justa en cuanto que es necesaria para salvaguardar la libertad de su reino. En este sentido Cenobia es una gobernante intachable, reina modélica, defensora siempre de la libertad de sus súbditos, ecuánime y prudente en el ejercicio justo del poder, que incluso sabe escuchar a sus soldados en sus pretensiones (pp. 328-329). También capaz no solo de ocuparse de las armas, sino también de las letras (está escribiendo una

${ }^{43}$ Faliu-Lacourt, 1979.

${ }^{44}$ Valbuena Prat, 1956, pp. 394-404.

${ }^{45}$ Calderón, Obras completas, ed. Valbuena Briones, 1959, tomo I, pp. 1003-1009; Valbuena Briones, 1965c, p. 235.

${ }^{46}$ Ruiz Ramón en su ed. de Calderón, «La hija del aire», Tragedias de Pedro Calderón de la Barca I, 1967; González Velasco, 1989, pp. 43-53.

${ }^{47}$ González Velasco, 1989, p. 46. 
Historia oriental), como corresponde al ideal del buen gobernante ${ }^{48}$. De ahí que el texto, desde esta perspectiva doctrinal de exposición de un modelo político basado en la justicia, haga acopio de emblemas y de una imaginería retórica ${ }^{49}$ propia de los tratados de educación de príncipes, como la descripción que hace Decio de Cenobia, dominadora de su caballo, que remite a modelos emblemáticos relativos a la condición moral positiva de la protagonista (p. 322):

a Cenobia, que a Palas parecía tan firme en un caballo que creyera que a los dos un espíritu regía, porque mostraba, aunque de furia lleno, que se pudiera gobernar sin freno

Esta misma presencia de lo virtuoso se manifiesta sin dobleces en la esfera privada, a la vez que concurren otros elementos, algunos privativos de lo femenino, como la ponderación de su belleza o la efusión sentimental que siente por Decio, refrenada en este caso por las obligaciones que impone el gobierno y el ejercicio del bien común. En su trayectoria, Cenobia conoce el triunfo y la derrota, pero en oposición a su rival, el déspota Aureliano, acepta estos cambios de Fortuna estoicamente y se preocupa más de su patria que de sí misma. Sin embargo, puesto que su pintura es bastante más convencional que en Ana Bolena y Semíramis, Calderón opta por someter al personaje a la pérdida temporal de su cuerpo político cuando, traicionada por Libio (un sobrino ambicioso del rey Abdenato), es hecha prisionera por Aureliano. La anulación transitoria en el transcurso de la acción del drama de su dimensión política conlleva un comportamiento más afin a los mecanismos tracistas comunes de la comedia con respecto a los personajes femeninos. En efecto, en ese lapso de tiempo que transcurre antes del desenlace de la obra, y que termina con la muerte del tirano a manos de Decio, Cenobia sufre celos amorosos, siente miedo ante la acumulación de

${ }^{48}$ Recuérdese que Enrique VIII en el inicio de La cisma de Ingalaterra es prototipo también del buen gobernante y defensor de la cristiandad, no solo con las armas, sino con la escritura de un libro contra la herejía luterana.

${ }^{49}$ Arellano señala múltiples ejemplos en el texto (2007, pp. 19 y ss.). 
agüeros y signos ominosos ${ }^{50}$, e intenta conseguir su libertad utilizando sus armas de mujer para seducir a Aureliano (pp. 381-382):

\author{
Probaré si puedo ver \\ humillado este rigor \\ fingiendo gusto y amor. \\ ¡Ahora sí que soy mujer! \\ ¡Ahora sí lo he parecido, \\ pues con mis armas ofendo \\ cuando a un bárbaro pretendo \\ vencer con amor fingido!
}

A la conclusión de la comedia, su cuerpo político queda restituido cuando Decio, erigido nuevo emperador, pida a Cenobia matrimonio. Lo que significa una reposición de la majestad y del ejercicio de su función pública a partir de la síntesis en un solo cuerpo de dos cuerpos naturales subordinados.

En los ejemplos señalados, la violencia tiene una presencia desigual y un tratamiento poliédrico en sus muchos matices. En Bolena y Semíramis tiene un valor instrumental, que responde a una estrategia razonable para la consecución y el mantenimiento de la ambición de poder. Es un medio que funciona fuera de toda consideración moral, cuyo alcance y su puesta en marcha es diferente. Ana Bolena hace un uso sutil e indirecto de la violencia, que se manifiesta a través de terceros. Ella nunca la ejerce, sino que deja que su agente sean otros personajes que caen bajo su perversa manipulación. Todo en ella es el resultado de un frío cálculo, desbaratado al final por exceso de confianza e imprudencia en la satisfacción de sus deseos. En Semíramis, sin embargo, la violencia, de nuevo instrumento de su ambición, es más anárquica, más irracional. Domina al personaje, que se presenta poseído por una ambición hidrópica que no controla y cuya devastación y violencia escapa a su control. Por contra, Cenobia, configurada como un exacto contramodelo de la «hija del aire», apenas tiene entidad como violencia arbitraria y amoral, pues responde a la doctrina jurídica légitima del tiranicidio.Y su guerra

${ }^{50}$ Como bien señala Arellano (2007, p. 17): «Las visiones de Aureliano y Cenobia pueden manifestarse o no visualmente: son alucinaciones de sus congojas interiores que admiten por ejemplo una representación en forma de sombras o quedarse en el mero nivel verbal, pero de uno u otro modo han de contribuir a la construcción de un espacio dramático onírico y dominado por los agüeros». 
contra Aureliano, desde esta perspectiva, no solo es justa sino necesaria en la defensa del bien común de su república. 


\section{Bibliografía}

Arellano, Ignacio, "Aspectos de la violencia en los dramas de Calderón», Anuario Calderoniano, 2, 2009, pp. 15-49.

Arellano, Ignacio, «Decid al rey cuánto yerra. Algunos modelos de mal rey en Calderón», en El teatro clásico español a través de sus monarcas, ed. Luciano García Lorenzo, Madrid, Fundamentos, 2006, pp. 149-180.

Arellano, Ignacio, "Glosas a La gran Cenobia», Acotaciones, 18, 2007, pp. 9-32.

Arellano, Ignacio, «Mujeres perversas y perversiones femeninas en Calderón», Hispanófila, 175, 2015, pp. 33-47.

«Autosemblanza de Felipe IV», "Apéndice II» de las Cartas de Sor María de Jesús de Agreda y de Felipe IV, ed. Carlos Serrano, vol. 5 del Epistolario español, BAE CIX, Madrid, RAE, 1958, p. 232b.

Boccaccio, Giovanni, De las mujeres ilustres en romance, Zaragoza, Paulo Hurus, Alemán de Constancia, 1494.

Cabantous, Michel, «Le schisme d'Angleterre vu par Calderón», Les Langues NeoLatines, 62, 1968, pp. 43-58.

Calderón de la Barca, Pedro, El mayor encanto, amor, ed. Alejandra Ulla Lorenzo, Madrid / Frankfurt, Iberoamericana / Vervuert, 2013.

Calderón de la Barca, Pedro, La cisma de Inglaterra, ed. Francisco Ruiz Ramón, Madrid, Castalia, 1981.

Calderón de la BARCA, Pedro, La cisma de Ingalaterra, ed.Juan Manuel Escudero Baztán, Kassel, Reichenberger, 2001.

Calderón de la Barca, Pedro, La gran Cenobia, en Comedias, I, Primera parte de comedias, ed. Luis Iglesias Feijoo, Madrid, Biblioteca Castro, 2006, pp. 307-396.

Calderón de la Barca, Pedro, La hija del aire (primera y segunda parte), ed. Uxue Baztán Salaverri, Madrid / Frankfurt, Iberoamericana / Vervuert, en prensa.

Calderón de la Barca, Pedro, Los tres mayores prodigios, en Comedias, II, Segunda parte de comedias, ed. Santiago Fernández Mosquera, Madrid, Biblioteca Castro, 2007, pp. 1007-1125.

Calderón de la Barca, Pedro, Obras completas, ed. Ángel Valbuena Briones, Madrid, Aguilar, 1959, tomo I, $4^{\text {a }}$ ed.

Caparrós Escalante, Luis, «Desbordamiento de la personalidad y horror moral en La gran Semíramis», Epos. Revista de Filología, Madrid, UNED, 2, 1986, pp. 49-58.

Delcourt, Marie, L'oracle de Delphes, Paris, Payot, 1981.

DumÉZIL, Georges, Ouranos-Varuna. Essai de mythologie comparée indo-européenne, Paris, Adrien Maisonneuve, 1934

Edwards, Gwynne, «Calderón's La hija del aire in the light of his sources», Bulletin of Hispanic Studies, 43, 1966, pp. 177-196. 
Edwards, Gwynne, "Calderón's La hija del aire and the classical type of tragedy», Bulletin of Hispanic Studies, 46, 1967, pp. 161-194.

Escudero BAztán, Juan Manuel, «El uso de la historia en Calderón. Tragedia e historia en La cisma de Ingalaterra», en La rueda de la fortuna. Estudios sobre el teatro de Calderón, ed. Juan Manuel Escudero Baztán et al., Kassel, Reichenberger, 2000, pp. 15-37.

EsCudero BAZTÁn, Juan Manuel, «La construcción de los caracteres en La cisma de Inglaterra. Convención e historia en el personaje de Enrique VIII", en Actas del $V$ Congreso Internacional de la Asociación Internacional Siglo de Oro (AISO), Münster 20-24 de julio de 1999, ed. Christoph Strosetzki, Madrid / Frankfurt, Iberoamericana / Vervuert, 2001, pp. 479-489.

Escudero BaztÁn, Juan Manuel, «El tirano calderoniano: la violencia del y para el poder y su reflejo en los sueños», en Calderón y la violencia. XVI Coloquio anglogermano sobre Calderón (Utrecht, 2011), ed. M. Tietz et al.,Vigo, Academia del Hispanismo, 2014, pp. 163-175.

Escudero Baztán, Juan Manuel, «Las estrategias del juego áulico en las comedias mitológicas calderonianas», Romance Quarterly, 64, 2016, pp. 66-76.

Faliu-Lacourt, Christiane, La madre en la comedia, Toulouse, Institut d'etudes hispaniques et hispano-américaines / Universidad de Toulouse-le-Mirail, 1979.

Fernández Mosquera, Santiago, «Las comedias mitológicas de Calderón: entre la fiesta y la tragedia. El caso de Los tres mayores prodigios», en Hacia la tragedia áurea: lecturas para un nuevo milenio, ed. Frederick A. de Armas, Luciano García Lorenzo, Enrique García Santo-Tomás, 2008, Madrid / Frankfurt, Iberoamericana /Vervuert, 2008a, pp. 153-179.

FERnÁndez Mosquera, Santiago, «El significado de las primeras fiestas cortesanas de Calderón de la Barca», en Calderón y el pensamiento ideológico y cultural de su época. Actas del XIV Coloquio Anglogermano sobre Calderón, Heidelberg, 24-28 de julio de 2005, ed. Manfred Tietz y Gero Arnscheidt, Archivum Calderonianum, 11, Stuttgart, Franz SteinerVerlag, 2008b, pp. 209-232.

Fox, Dian, Kings in Calderón: a study in characterization and political theory, London, Tamesis, 1986.

GonzÁlez García, José M. ${ }^{a}$, Metáforas del poder, Madrid,Alianza Editorial, 1998.

González Velasco, M. ${ }^{a}$ Pilar, Variaciones de Segismundo en la obra de Calderón, Salamanca, Universidad de Salamanca, 1989.

Hesse, Everett W., «Los dos retratos de Semíramis», Estudios sobre el Siglo de Oro en homenaje a Raymond R. MacCurdy, Madrid / Alburqueque, Cátedra / University of New Mexico Press, 1983, pp. 151-157.

Hilborn, Howard W., A Chronology of the Plays of don Pedro Calderón de la Barca, Toronto, Toronto University Press, 1938.

Kantorowicz, Ernst H., Los dos cuerpos del rey. Un estudio de teología política medieval, Madrid, Alianza Editorial, 1985. 
MCKendrick, Maleeva, Woman and society in the Spanish drama of the Golden Age, Cambridge, Universidad de Cambridge, 1974. [Sobre Semíramis pp. 203207]. Manejo la reedición de 2010.

Mckendrick, Maleeva, El teatro en España (1490-1700), ed. José J. de Olañeta, Palma de Mallorca / Barcelona, Libergraf, 1994.

Paredes, Alejandro, «Nuevamente la cuestión del metateatro: La cisma de Inglaterra», en Calderón. Actas del congreso internacional sobre Calderón y el teatro español del Siglo de Oro, ed. Luciano García Lorenzo, Madrid, Centro Superior de Investigaciones Científicas, 1983, vol. I, pp. 541-548.

Parker, Alexader A., "Henry VIII in Shakespeare and Calderón: An appreciation of La cisma de Ingalaterra», Modern Language Review, 43, 1948, pp. 327357. Reimpreso en John E.Varey (ed.), Critical Studies of Calderón's Comedias, en Pedro Calderón de la Barca. Comedias, London, Gregg / Tamesis, 1973, vol. XIX, pp. 47-77.

PARker, Alexander A., "La religión y el estado: La cisma de Ingalaterra», La imaginación y el arte de Calderón, Madrid, Cátedra, 1991, pp. 305-348.

Petro del Barrio, Antonia, La legitimación de la violencia en la comedia española del siglo XVII, Salamanca, Universidad de Salamanca, 2006.

Rivadeneyra, Pedro, Historia eclesiástica del cisma del reino de Inglaterra, Madrid, Imprenta Real, 1674.

Rivadeneyra, Pedro, Obras escogidas, ed.Vicente de la Fuente, Madrid, Biblioteca de Autores Españoles vol. 60, 1952. La introducción ocupa las pp. 177-79; el texto, pp. 181-357.

Rogers, Daniel de W., «La imaginación de Semíramis», Hacia Calderón: segundo coloquio anglogermano, Hamburgo 1970, ed. Hans Flasche, Berlin / New York, Gruyter, 1973, pp. 171-179.

Ruiz Ramón, Francisco, Tragedias de Pedro Calderón de la Barca I, ed. e introducción de Francisco Ruiz Ramón, Madrid, Alianza, 1967.

Ruiz Ramón, Francisco, Calderón y la tragedia, Madrid, Alhambra, 1984.

Ruiz Ramón, Francisco, Paradigmas del teatro clásico español, Cátedra, Madrid, 1987.

Ruiz Ramón, Francisco, «Mitos del poder: La vida es sueño», En torno al teatro del Siglo de Oro (Jornadas VII-VIII, Almería), Almería, Instituto de Estudios Almerienses, 1992, pp. 61-77.

Sargent, Cecilia V., A study of the dramatic works of Cristóbal de Virués, New York, Instituto de las Españas en los Estados Unidos, 1930.

Shapiro, Marianne, «Semiramis in Inferno V», Romance Notes, 16, 2, 1975, pp. 455-456.

Shergold, Nigel D. y John E.VArey, «Some Early Calderón Dates», Bulletin of Hispanic Studies, 38, 1961, pp. 275-276.

Stoll, Anita K. y Dawn L. Smith, The Perception of Women in the Spanish Theater of the Golden Age, London / Toronto, Bucknell University Press, 1991. 
Stoll, Anita K. y Dawn L. Smith (eds.), Gender, Identity and Representation in Spanish Golden Age, Lewisburg, Bucknell University Press, 2000.

Valbuena Briones, Ángel, Perspectiva crítica de los dramas de Calderón, Madrid

/ México / Pamplona, RIALP, 1965. [Capítulo dedicado a La hija del aire: pp. 230-238].

Valbuena Prat, Ángel, Historia del teatro español, Barcelona, Noguer, 1956. [La hija del aire: pp. 394-404]. 